\title{
THE HISTORY OF ANCIENT PAPER MAKING AT WENZHOU AREA, ZHEJIANG, CHINA
}

Pan Mengbu, Senior Research Librarian, Wenzhou City Library, China, and Zhang Yongsu, Associate Research Librarian, Wenzhou City Library,China

\begin{abstract}
The authors of this paper give a brief account of the history of ancient papermaking in the Wenzhou area, China. This paper also concludes that Wenzhou has played an important role in China's papermaking history through the textual research on the exact original time and techniques of "Wenzhou Juan Paper" in the Song Dynasty (960-1279 A.D.), "Nanping Paper" in the Yuan and Ming Dynasties (1279-1644 A.D.), and the mode of joint venture of the papermaking industry in the Qing Dynasty (1644-1911 A.D.), and also the "living fossil" of papermaking art and the papermaking workshop groups of Si Lian Dui in Zheya, and Huajian Paper in Taishun Country.
\end{abstract}

\section{KEY WORDS}

Papermaking

Wenzhou Juan paper

Nanping paper

Huajian paper

Si Llian Dui

\section{HISTORY OF WENZHOU JUAN PAPER}

The earliest records about ancient papermaking in Wenzhou are found in Cheng Kai's San Liu Xuan Za Shi (程棨 三柳轩杂识Miscellaneous works of San Liu Xuan) in the Song Dynasty. It said that: "Wenzhou produces Juan paper, white and firm, similar to Korean paper. Most of the paper mills located in the southeast of Wenzhouproduce papersomeone thoughtwas one of the best papers in China, even superior to Youquan paper and the others. Because of lower production, the paper was not offered as articles of tribute to the emperors until the Zhihe reign (1058). Afterward, more and more dignitaries preferred to use the paper, so that the papermakers could not bear it. Up to the Qian reign of the Wu Dynasty, the papermakers became tax-free persons, so the paper was named Juan (exempt) Paper." However we can find two mistakes in this record: 
First, the time given for when Wenzhou paper was first submitted to the imperial court of the Song Dynasty is wrong. The book of Taiping Yuangyu Ji, Yue Shi (乐史 “太平寰宇记” Records in Taiping Yuangyu Period in History of Music in Song Dynasty, see Vol. 99) said that: "Wenzhou submitted the native products, which included shark fish, Juan Paper etc.. The book was written in the Taipingxingguo Reign, and recorded what had happened in the early North Song Dynasty. Apparently, it is wrong that Wenzhou paper was "submitted as the articles of tribute to the imperial court of Song Dynasty since the year of the Zhihe Reign (1058 A.D.)." Another record in the book of Yuanfeng jiuyuzhji,vol.9 (王存等.元丰九域志 $a$ record of nine territories in Yuanfeng reign), which was written in the Song Dynasty by Wang Chun etc. revealed that, "Wenzhou submitted five pieces of shark skin and 500 pieces of paper," which clearly mentioned the quantity.

Second, the origin of the paper's name was wrong. The same mistake could also be found in Mr. Zhou Hui's book of Qingbo biezhi (周恽 《清波别志》N Notes of Mr.Qingbo, see vol.1) in the Song dynasty, which said that: "In Tang dynasty, the papermakers could be exempted from taxation and service, so the paper was named Juan (exempt). The paper made in Yongjia, at that time, was attracted by the literati and officialdom with the special function of the paper on calligraphy and painting, vying with each other to collect the paper with high price because that the paper could meet their needs in pursuit of the art, just as the Chenxintang Paper etc." Mr. Zhao Yushi, a scholar of the Song Dynasty, gave a clear explanation for it in his book of Bin tui lu (赵与岶 《宾退録》 vol.2), which quoted from Chao ye lei yao (《墘野类要》 The important affairs in state and society, classified, Vol. 2), and said that: "In Lin An the paper sold by some paper sellers was treated with size and starch to enhence (sic) brightness and smoothness. So it was called Juan (bright) Paper. Juan means clean and white. Shi jin (《诗经》 the book of odes) says: 'Choose a good day to cleanse for cooking.' Zhou li (《周礼》 the Ritual of Zhou) said, 'Unclean eunuch will be dismissed', the name of Juan (cleanse) is after that. Also it was recorded in a book of Hezhe zhuang, Wu dai, (《五代何泽传) the Biography of Hezhe in a history of Five Dynasties), "The Chinese common people were afraid of being a soldiers, and often cut their own meat as medicine to cure their parents, or lived in the temporary house in mourning beside the graves of their deceased parents in order to evade the military service to the government. The number of exempting orders annually issued by the Treasury Department were so large that the local governments were asked to provide the paper named Juan Paper as a scutage." The name of Juan Paper looks as if it were similar to the meaning of exempting, but it does not mean exempting. It is obvious that Wenzhou Juan Paper was named after its brightness and whiteness, not after exempting the papermakers from taxation and service or corvee. So the paper had another name Juan Jiang Paper. As recorded in vol.41 of Dili zhi and Song shi (《宋史》, 《地理志》 geographical records in a History of the Song Dynasty, Vol. 88) Wenzhou "submitted shark skin, Juan Jiang Paper." Another book of Qing yi tong zhi (“清一统志》 a record of unifying Qing Dynasty, vol.235), which clearly explained 
for it," and "Wenzhou's Juan Jiang Paper made with wheat (or rice) flour, began to be submitted to the imperial court in the Song Dynasty." According to the explanations of Shuo wen (《说文) origin of Chinese characters), originally, Juan means a kind of worm on the horses, then clean and white,the last extensive meaning is exempting. Also as explained in the book of Zhen zhi tong (《正字通) a book for correcting Chinese characters), "The people of Tang Dynasty made paper from paper pulp with extract of size and starch for smoothness and brightness,and named it as Juan Paper." Mr. Gu Qiyuan of the Ming Dynasty in the series book of Shuolue (顾起元 《说畧》 An outline of the classics Vol. 15) also quoted the poem by Mr.Li Shiming, the first emperor of the Tang Dynasty: "Water shakes gentlely with bright waves, like the bright and beautiful flower floating. Tang has Juan Paper, which is also named Yan-bo (waving) writing paper, because the paper has wavelike texture." Obviously, the Juan Paper was named in the early Tang Dynasty first. Wenzhou began making paper also in the Tang Dynasty and paying tributes to the imperial court in the early Northern Song Dynasty.

At that time, Wenzhou Juan Paper, which was good in quality and suitable for painting, was as well known everywhere as the famous papers such as the Chenxintang paper in South China, Youquan paper in Yuhang County, Korean paper etc. It even went by the name of a wonderful paper in the Song Dynasty, just as Mr. Yang Wanli of the Song Dynasty described in Chengzhai ji (杨万里 «诚斑集) selected works of Yang Wanli Vol.180), All presented articles indicating the Juan Paper, writing brush and ink were top grade. (《答徽怢椨任寺丞) “Responding to Ren Shi Cheng, the prefecture magistrate of Huizhou"). So the paper became favorites of past scholars, for example, Mr. Zeng Ji of the Song Dynasty in the poem "Sending Professor Zhang Qinian from Shaoxing to be the Yongjia's education official” (曾几 《送绍污长耆年教授之永嘉学官》 see vol. 4 of Chashan ji 《茶山集》, works of Mr.Zeng ji), also complained he had no Juan Paper to record his unhappiness. Mr. Wu Zuo of the Qing Dynasty highly praised the paper in Nansong zashi shi (吴焯《南宋杂事诗》 Miscellaneous Poems in Southern Song Dynasty, Vol.2). The paper was not only favored by the common people, but also recommended to the government and imperial palace for use. Mr. Tao Zongyi mentioned it in the book of Shuo fu (隐宗仪《说郛》 On the five classics Vol. 21), and said that: “Since Shang Yuan Emperor period of Tang Dynasty (760-761 A.D.), those from the emperors to the government officials all take Juan Paper for official use. From the Li Zong Emperor Period of the Song Dynasty (1225-1264 A.D.), the paper made of bamboo and the ivory of the imperial seal, were used as a memorial to the emperors by the close ministers, which were known as the Royal wooden tablet for writing. It is really an invention." Besides, it was also widely used for copying Buddhist Sutra. Mr. Zhang Xiumin mentioned that the printing art in the Wuyue State in the Five Dynasties (907-960 A.D.), "Wenzhou produced Juan Paper, which was white, smooth and firm, and was superior to Korea paper, which provided the material conditions for printing and copying Sutra." (See the Selected Papers of Mr. Zhang Xiumin on Printing History 张秀民印刷史论文集. In 1965, it was found in the 
Baixiang (white elephant) Pagoda, which the Amitayur-dhyana-sutra (佛说观无量寿佛经) copied in the 3rd year of the Emperor Da Guan of the Song Dynasty (1109 A.D.). The paper was Juan Paper, and it is the earliest specimen of the paper found in Wenzhou.

\section{RAW MATERIALS OF WENZHOU JUAN PAPER}

What kinds of materials were used to produce the Wenzhou Juan Paper? The existing local historical literature and documents in the Wenzhou area have not yet given an exact answer to this question. Someone believed that the raw material of the Wenzhou Juan Paper was tender bamboo, which was based on two factors. One is from a book of Yunju mishu (芸局秘书rare books in Yunju) in the Song Dynasty, whichsaid that: "The materials of paper include hemp in Sichuan, tender bamboo in Jiangsu and Zhejiang, mulberry bast in the North China, vine in Yanxi and moss in the seaside area"; the other is that Wenzhou is rich in bamboo resources, and Mr. Wang Zan wrote in Hongzhi Wenzhou fuzhi (王赞 《弘治温州府志 $a$ Record of Wenzhou prefecture compiled in Hongzhi reign, vol.7), that Wenzhou produces "stone bamboo, its summer. The shoots is sweet, the leaves can be made into paper." Besides, there were the other kinds of bamboo, such as moso bamboo, bitter bamboo, glaucous bamboo, Omei mountain bamboo, lotus bamboo, square bamboo, fishscalie bamboo, robert young bamboo, giant timber bamboo, black bamboo, spotted bamboo, mat bamboo, fishpole bamboo, lady palms hedge bamboo, fernleaf hedge bamboo, early spring shoot bamboo, chequer-shaped indocalamus and so on. Therefore, it was reasonable that tender bamboo was used as the raw materials for Wenzhou Juan Paper. In fact, Mr. Song Yingxing's book of Tian Gong Kai Wu (宋位星 天工开物 The Development of Materials formed by nature) has a clear explanation, "Sangpizhi, i.e mulberry paper, extremely thick. Yongjia Juan Jiang Paper is also made from the bast fiber of mulberry" (See Vol.13,Making bast paper 造皮纸. Therefore, Wenzhou Juan Paper is a kind of white, dense, well proportioned, lubricative paper.

\section{GROUP MILLS OF SILIANDUI FOR PAPER MANUFACTURE}

Although the manufacturing system of Juan Paper was lost long ago, the productive techniques have been recorded in detail in the book, Hongzhi Wenzhou fuzhi (王瓒 弘治温州府志 a Record of Wenzhou prefecture compiled in Hongzhi reign, vol. 7). Fortunately, the ancient manufacturing method of Wenzhou Juan Paper has been preserved. It is called Method of Jiang-Fen-Yan. It says that: "The method shows as follows. First, put the rice and wheat flour mixed with mirabilite in water and cooked. When it was cool, we had to take the extract for use, and size the paper with glues or gums and alum. After drying, we had to brush the drug ex- 
tract on both sides of the paper with a big brush, and finished with wax like playing cards. Then we wipe and grind them with pieces of the coarse cloth. In the past, the paper was taken to the government for official use, but now it is ceased. The method recorded here is used just as memorandum of past for the later generations." It is clear to introduce the manufacturing process of batching method of manufacturing Juan Paper. Yan means thick juice, here for the drug extract, Jiang i.e size, a gelatinous or glutinous substance as glue or gum, Fen i.e starch of rice or wheat, that will enhence the whitness of Juan Paper; mirabilite applied to enhence the flexibility of Juan Paper. The whole procedure is to cook starch, size, mirabilite until a drug extract was gained, and then the paper was treated with a series of complex and strict procedures, such as sizing with glue and alum, drying, brushing the drug extract, redrying, waxing, finishing, to prevent aqueous solution in writing. As recorded in Jiang Zhun's book of Qi hai suo tang, (姜准岐每涢谈On trivial affairs in a remote seaside town vol.11) in the early Ming Dynasty, the Wenzhou government had established the Paper Board in the old Street of Quxi to administor the manufacturing, paying tributes and distribution of Wenzhou Juan Paper. During the Xuan De Emperor period (1426-1435 A.D.), Mr. He Wenyuan, the mayor of Wenzhou Prefecture, wrote a memorial to the emperor and said that: "We are worried that the disease was a great distress to the people. We tried our best to change the water, but because of papermaking and turned into black." After the emperor sent the people to check and confirmed it, the tribute for Juan Paper was exempted. Thereafter, the manufacturing system of Wenzhou Juan Paper could not be handed down from the past generation. It is pity to lose the quality paper.

The Wenzhou Juan Paper has already disappeared, while in some places of Wenzhou like Zheya, Quxi, this kind of paper production has never ceased. When did the Zheya produce the paper? Mr. Huang Huai of the Ming Dynasty recorded in "Mr.Lin's Epitaph, Who Was a Retirement Scholar" that the ancestors of Zheya, who immigrated from Naping County, Fu Jian Province in the early Ming Dynasty to avoid the war brought the techniques of manufacturing Ping paper. After immigrating here, they found that Zheya was rich in water and suitable for growing bamboo for papermaking. Therefore, the techniques of Nanping papermaking fell upon the Zheya ground and took root. They built water-powered trip hammers, paper troughs, and used the hydraulic water to smash bamboo into paper pulp, and finally produced paper which is still called "Nanping Paper." In 1999, a group of experts from the China Printing Museum paid a visit to Zheya and were astonished to find the techniques of ancient China papermaking had been preserved completely. They suggested that the papermaking workshop groups, locally named Siliandui (Four Joint Water-powered Trip-hammer), were the "living fossils" of papermaking. The Siliandui is located in Paper Mountain between Zheya and the West Bank in Ouhai County of Wenzhou City, Zhejiang. Since the later Yuan and the early Ming Dynasties, the Siliandui (Four Joint Water-powered Trip-hammer) had been used to produce paper, and now it has become a rare exist- 
ing example of the ancient technique of papermaking. As one of the four greatest inventions in China (i.e. papermaking, printing, the compass, and gun powder), the techniques of papermaking had a unique significance in its traditional handicraft workshops. Therefore, it could be considered a miracle in the history of papermaking that the Siliandui (Four Joint Water-powered Trip-hammer) was preserved so perfectly and completely from the whole process to the workshop's construction. The groups of Siliandui (Four Joint Water-powered Trip-hammer) used the essence of techniques in production of Ping Paper, of which much matched to the records in the book, Tian Gong Kai Wu' (天工开物 The Development of Materials formed by nature) by Mr. Song Yingxing, a scholar in the Ming Dynasty. Some techniques are even earlier. It is valuable that the series of practicalities and historical information, such as the techniques of papermaking, tools and facilities of production, as well as the working environment and working environment for producers, are preserved so perfectly and completely. In 2001, the Siliandui (Papermaking Workshop Groups), was approved as the "Most Important National Preservation Cultural Relic" by the State Council of China. In 2004, Ouhai Country submitted the Siliandui to the 28th World Heritage Conference and applied as the World Cultural Heritage.

\section{THE STEPS FOR PROCESSING THE WENZHOU JUAN PAPER}

The process of primitive papermaking in Zheya follows these steps: First step. To take off the bamboo's leaves and cut the bamboo into around one meter. Then, we'll split the bamboo into strips and tie up into the bundles. The workers called it "Sha.".

Second step. To put these bamboo bundles under the blazing sun in order to make them dry.

Third step. To put these bamboo bundles into a stone pond full of guicklime and press them with big stones. This stone container can hold the capacity of $1,500 \mathrm{~kg}$. of the bamboo bundles.

Fourth step. After 3-5 months, take the bamboo bundles out and put them under the sun for drying and then put them into clean water to wash the lime away and be ready for use. We call this process "pickling bamboo."

Fifth step. To put the pickled bamboo into the pit of the water power trip hammer, which is a simple hydraulic tool with a big water wheel driven by water and rotating as a turbine. It can propel a four-meter long wooden hammer slightly to crush the pickled bamboo into golden, fluff pulp. We call this process "smashing the bamboo bundle," which is the only step in which the workers can use external force in the entire traditional method of papermaking.

Sixth step. To put the fluff pulp into the stone container with clean water and stir it completely and drain the water. It becomes the pulp. We call this process "stirring the fluff pulp." 
Seventh step. To put the pulp into clean water and stir up thoroughly and use the sieve, which was made of small bamboo strips and scoop out the paper membrane. Then, to pile up these paper membranes and use a wooden board to squeeze out the water. We call this process "scooping out paper."

Eighth step. To depart and dry the paper. The piled paper membranes are very easily broken. Usually this work should be done by female workers who are clever and deft and careful. After taking the membrane from the piles, the women workers had to put it on the absolute level ground or on the wall for drying.

That's all for the processing steps of Zheya paper manufacturing. This is exactly the same as the technique of papermaking creatd by Mr. Cai Lun (? 121 A.D.) about 2000 years ago.

\section{JOINT VENTURE IN THE CONSTRUCTION OF THE WATER- POWERED HAMMER}

On July 2001, a stone tablet named "Stele for building water-powered triphammer in Cao Dui Lu Xia Tang Tan of Tang Zai Village" was found in the the north wall of Tang Tan, the hydraulic trip hammer which was located in the Tang Zai Village of West Bank, Ouhai County. This stone tablet was made as a contract in Pan's family to create the shared stocks in the construction of the water- power trip hammer. This rectangular stone tablet was made of bluestone with the size of $57 \mathrm{~cm}$. (L) x $23.5 \mathrm{~cm}$. (W). The text of the stone tablet was seven lines with thirteen characters in each line. It reads that:

"We, the kinfolks of Pan's Family, including Zhi Yu, Zhi Ren, Mao Jiu, Zhi Guang, Zhi Jin, Mao Jin and Mao Tong, made concerted efforts to build one water-powered trip-hammer, which was located in our villadge, and called Cao Dui Lu Xia Tang Tan. After paying the tax revenue with grain, this stock will be divided into seven sharings and thereafter, it will never be allowed to increase any sharings. During the rice havesting season, the rice comes and the machine starts to grind the rice first. There is no argument. It will be fined 1,000 coins if anyone made argument. Everyone should obey this rule. Founded by Pan's Family on Feb., 55th year of Qian Long Emperor (1790 A.D.)"

On June 9, 2002, Mr. Wu Mingze, who is an associate researcher of the Cultural and Museum of Longway District, Wenzhou City, found a cornerstone of a waterpowered trip-hammer in Zheya. This cornerstone is a stone tablet, with engraved characters from the 4th year of Yong Zheng Emperor (1727AD). It described the local resident built papermaking mill of water-powered trip-hammer with joint stocks. This new discovery recorded the exact time of joint stocks papermaking in Zheya 65 years earlier. Actually this mode of cooperation is the rudimentary way of the modern shareholding economy. In ancient China, the water-powered triphammer, as one of the largest-scale machinery equipment, was exactly a mechani- 
cal pump equipped with a complete series of facilities including water supply, driving and rigging system, processing, braking and lubricating devices. In the forms of production of papermaking based on a family as a unit, it is the most economical, the most reasonable way to employ this kind of cooperation to invest in equipment for the large-scale prodution of paper pulp, which requires large amounts of capital and equipment.

\section{PAPER MARKET IN THE WENZHOU AREA}

In the marketing chain, Ping Paper is distributed by the specialized paper selling firms, which purchase paper from the paper manufacturers, and then sell it to the market. This business model of decentralized production and centralized marketing, in all times, has been adopted, the vitality of which is still quite strong. The old Street of Quxi also was the paper distribution center of Wenzhou from ancient time to the middle of the 20th century, an extension of the "Most Important National Preservation Cultural Relic" Wenzhou Four Joint Water-powered Triphammer papermaking workshop group. In the past, Wenzhou had many famous paper firms, which including Hu Chang Ji, Huang Zheng chang, Chen Maolai, Lin Changji in Quxi town, Tao Shengji and Zhang Renliu in Xiongxi town, and Yang Changji in Guoxi town etc. At the beginning of 2006, two remnant stone tablets of the Qing dynasty were found in the old street of Quxi town.

Stone Stele 1, it reads:

"Announced by Chang, prefect of Wenzhou prefecture in Zhejiang, Chen, magistrate of Yongjia County in Wenzhou, Peng, magistrate of Ruian County in Wenzhou."

The engraved stele is made for an eternal ban. According to the report submitted by the elders, Mr. Zhang Han and others from both of the counties, Yongjia and Ruian, they are residing in the area of mountains and villages and living on papermaking because of barren lands. They used to carry the paper on their shoulders with a pole to Chaozhi Street, or to the junction of Yongjia, Quxi, Rongxi for sales. In the 30th year of Daoguang Empeo (1850 A.D.), Mr. Wu Juhuai, a firstdegree graduate (collegian of imperial academy), entrusted his men with the business to open the broker houses in the key traffic sites where they passed by, nominally called transit trade, actually acted as blackmailers to extort profits from the papermakers, so that the local citizens as Lin Tingcai, Zhang Qipeng, a first-degree licentiate (government student), etc, repeatedly charged them with extorting.

The prefect of the prefecture instructed the magistrate of the county to issue a ban with engraved inscriptions on record. Unexpectedly the stone tablet was ruined during a turmoil. At present, a few of profits pursuers want to follow the bad custom and open broker houses to extort and exploit civilians, this ... (incomplete below)."

Stone Stelet 2: (It only shows an outline as below because of the fragmentary text) "Announced by the magistrate of Yongjia County under the Wenzhou Pre- 
fecture, according to the report submitted by the elders, the old peasant $\mathrm{Mr}$. $\mathrm{Wu}$ Jiming, Mr. Pan Rui Qing, Mr. Pan Qiyuan, who reside in Yongjia County, living on planting bamboo and papermaking, when they wanted to sell paper in Quxi, or elsewhere they are blackmailed extorted by the someone, the leading blackmailer named $\mathrm{Mr}$. $\mathrm{Wu}$, who colluded with some broker houses to extort transit dues from them in the name of transit trade. Now the case is under investigation approved by prefectures and county. Unexpectedly another person named $\mathrm{Mr}$. $\mathrm{Xu}$, also opened a broker house called Ru Risheng, who did not follow the rules on fair trade but Wu's bad habits extorting transit dues from paper sellers against their willings by obstructing and meddling. Because it has made a bad result that influenced the lives of common people so much that we decide to issue an announcement carved on the stone to ban the wrong doing forever. Hereby we reaffirm that all the people should follow the rules of fair trade, and any middleman or broker house cannot do anything against sellers' willings, no obstacle for their selling and buying, no monopolization allowed. If anyone is found to disobey the order, he should be punished severely after confirming and so on." According to the existing text of inscription, it is possible to determine the following facts: First, Quxi and Xongxi in Ouhai, as well as Chaozhi in Ruian are the distributing centers in the papermaking industry of Wenzhou area; second, some evil local forces of and broker houses repeatedly set up trade barriers to extort from the papermakers or to monopolize the market, the papermakers repeatedly appealed to both the governments, the Wenzhou Prefecture also repeated the orders, even carved on stone tablets to ban any of the illegal operations and market monopoly, to safeguard the interests of the public as well as the order of the paper market. It is very important as the two stone tablets have filled a gap in the historical documents and data of the Wenzhou paper industry. Furthermore, it is also very valuable for those who are interested in the study of the modern history of business development of Wenzhou are as well as its history of the market towns that the fragmentary records on the two stone tablets reflecting what happened in the production and market trade of the commodity between the countryside and towns of Wenzhou during the late Qing Dynasty.

\section{MANUFACTURE OF PAPER IN TAISHUN COUNTY, WNZHOU AREA}

In addition to Nanping paper, the production of Wenzhou Huajian, Mulberry paper production has never ceased in Wenzhou. "Tai Shun's Hua Jian, Yong Jia's Mulberry paper both are produced unprosperously because of their poor quality." (See Mr. Lin Datong's jianzhishuizhai tanxiao, 林大同鉴止水斋谭屋 Trivial talks at Study of Jiang Zhishui) In Lingbei of Taishun there have existed as many papermaking workshops as in the Xiaochun village and Beipai, but Lingbei's papermaking is representative of the manual papermaking base in Taishun because of numerous practitioners, large scale production (the papermaking workshops once over dozens during its most prosperous time for papermaking). In the northwest to the town of 
Taishun, Lingbei Township, inhabited by $\mathrm{Mr}$. Xu, as recorded in A genealogical record of $X u$," that its paper industry started in the Ming Dynasty.

The process of basic papermaking in Taishun is the same as that elsewhere.

The first step is to "choose bamboo": the bamboo shoots growing in Qingming (at the beginning of the spring season), after about thirty days, they can be used as the raw material for papermaking. The skin of the Bamboo should be removed, then cut into sticks about two meters long, tied as a bundle of about $25 \mathrm{~kg}$.

The second step is to "pickle bamboo," fill the special pool full of water with a layer of bamboo bundles, then sprinkle quicklime over them, depending on the size of the pool, repeat the operation until the entire pool is full, but the water in the pool must cover the bamboo bundles. After being macerated for forty days, dry up the pool of limewater, remove the bamboo bundles, and then set up a wooden stand in the pool, pile up the bamboo bundles on it, covered with bark or bamboo skins, and then use the brick and stone on top of the stack to press it. When the bamoo bundles are air dried (about seven days), followed constantly on watering and draining about seven times. Then again fill the pool with water, bamboo bundles soaked in the water a month later, until the bundles have been rotten, at this time, can "pick up the materials," remove the debris from the bamboo pulp.

The third step is to "tread materials." After removing the debris, put the bamboo pulp into a big stone mortar, keep stamping with feet, make bamboo pulp into paste. It is said that, in the entire papermaking processes, only three people may be called Master, one of whom is the master to tread materials. Another two were the masters of scooping pulp and drying paper; the paper quality depends on the sincere co-operation between them; any errors in the whole procedure will have a direct impact on the quality of paper.

The fourth step is to "scoop out pulp". After treading the bamboo pulp, it is removed to the paper container with water mixed with "glue." "Glue" is a local name for a mucus from plants growing in the mountains. In the book of Tian gong kai wu (天工开物The Development of Materials Formed by Nature), it is known as "paper drugs." Pulp mixed with the "glue" that could play a very good role in the regulation, make the paper more white and flexible. The tool for scoopng out paper pulp is called a "paper sieve" which was made of small bamboo strips.

Fifth step is to "Dry paper," After scoopng the paper pulp, the paper membranes will be piled up approximately fifty centimeters, and then it will be pressed by the rock on the top. The water will be squeezed out. After that, the paper membrane will be put on the vertical level wall of a kiln for drying. This kiln is wide in the upper part, but narrow in the bottom, which is different from the porcelain kiln. After drying the paper sheets will be taken off and stacked up. This process is different with natural drying of Paper Hill. 
will be put on the vertical level wall of a kiln for drying. This kiln is wide in the upper part, but narrow in the bottom, which is different from the porcelain kiln. After drying the paper sheets will be taken off and stacked up. This process is different with natural drying of Paper Hill.

\section{CONCLUSION}

China is one of the earliest countries where civilization and culture flourished in the world. Thousands of years ago, China invented the techniques of papermaking. Therefore, China is the cradle one of the earliest countries of civilization. Wenzhou occupies a very important position in China's papermaking history. Wenzhou Juan Paper is famous all over the world. During the endless and continuous stream of history, Wenzhou Juan Paper has enjoyed its own past glorious days. The group of Siliandui (the four joint water-powered trip-hammer) papermaking workshop in Paper Hill has its special traditional technique. This is also symbolic that Wenzhou is a place propitious for giving birth to great men, and a place of profound traditional cultural heritage. Siliandui is an important part of the Wenzhou regional culture. It belongs not only to Wenzhou, but also to China, as well as to the world.
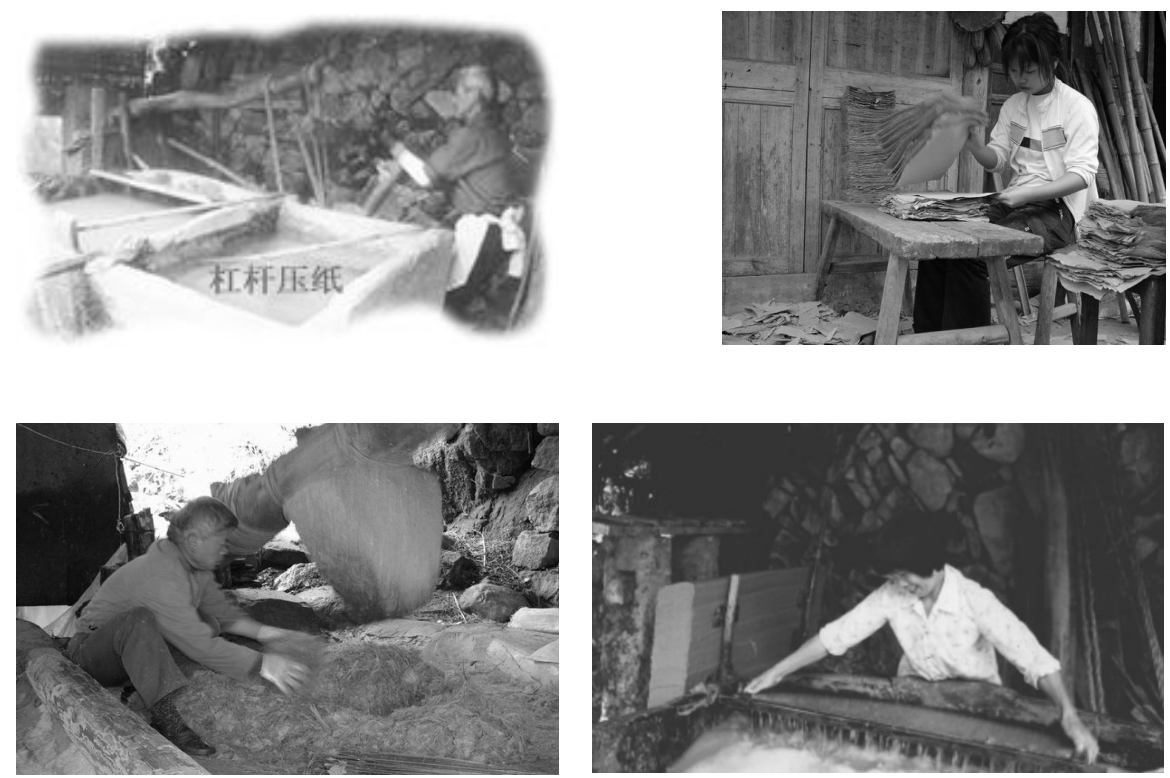


\section{REFERENCES}

1. Taiping Yuangyu Ji, Yue Shi (乐史太平寰宇记 Records in Taiping Yuangyu Period

2. In History of Music in Song Dynasty) [M]. Imperial Collection of Four. Shanghai: Shanghai Ancient Books Publishing House, 1987.

3. Wang Chun et al,Yuanfeng jiuyu ji,vol.9 (王存等.元丰九域志 a record of nine states in Yuanfeng reign) [M]. Imperial Collection of Four. Shanghai: Shanghai Ancient Books Publishing House, 1987.

4. Zeng Ji Chashan ji (曾几 茶山集, works of Zeng ji) [M]. Imperial Collection of Four. Shanghai : Shanghai Ancient Books Publishing House, 1987.

5. Zhou Hui, Qingbo biezhi (周恽 清皮志 Notes of Mr.Qingbo) [M]. Imperial Collection of Four. Shanghai: Shanghai Ancient Books Publishing House, 1987.

6. Zhao Yushi, Bin tui lu (赵与㞱 宾退録) [M]. Imperial Collection of Four. Shanghai : Shanghai Ancient Books Publishing House, 1987.

7. Yang Wanli Chengzhai ji (杨万里 诚斑集 selected works of Yang Wanli) [M]. Imperial Collection of Four. Shanghai: Shanghai Ancient Books Publishing House, 1987.

8. TuoTuo et la.Song Shi (脱脱宋史 History of the Song Dynasty) [M]. Beijing: China publishing house. 1977.

9. Tao Zongyi, Shuo fu (缸宗仪说郛 On the five classics [M]. Imperial Collection of Four. Shanghai: Shanghai Ancient Books Publishing House, 1987.

10. Wang Zan, Hongzhi Wenzhou fuzhi (王珗 弘治温州府志 a Record of Wenzhou prefecture compiled in Hongzhi reign [M]. Shanghai: Shanghai Academy of Social Sciences Publishing House, 2006.

11. Gu Qiyuan. Shuolue (顾起元说畧An outline of the classics [M]. Imperial Collection of Four. Shanghai: Shanghai Ancient Books Publishing House, 1987.

12. Nansong zashi shi (吴焯南宋杂事诗Miscellaneous Poems in Southern Song Dynasty [M]. Imperial Collection of Four. Shanghai: Shanghai Ancient Books Publishing House, 1987.

13. Jiang Zhun. “Qi hai suo tang, (姜准岐海埙谈 On trivial affairs in a remote seaside town [M]. Shanghai: Shanghai Academy of Social Sciences Publishing House, 2002.

14. Zhang Xiumin's Papers on History of Printing 张秀民印刷史论文集 [M]. Beijing: Printing Press, 1988

15. Xu Dingshui. A report on sorting out the white elephant tower built in Northern Song Dynasty in Wenzhou [J]. magazine of cultural relics 1987 (5)

16. Huang Zhou Song. Stone tablets of Qing dynasty found in Quxi [J]. Wenzhou Daily 2006 1.4.

17. Wu Mingze. Inscriptions and stone tablets of past dynasties in Wenzhou, Book two [M]. Shanghai: Shanghai Academy of Social Sciences Publishing House, 2006. 
18. Xue Yiquan. The disappearing papermaking workshops [J]. Wenzhou Daily 2004.6.26

\section{ABOUT THE AUTHOR}

Mr. Pan Mengbu is a senior research librarian in the Wenzhou City Library, China, and the head of the Old and Rare Book Department in the Wenzhou City Library. His research concentrates on collation of old and rare books, collecting and cataloguing local documents, and the science of editions and bibiliography. He has published the books of "Selected Famous Works of the Past Dynasties in Wenzhou Area," "A Compilation of Genealogies in Wenzhou Area," "Union Catalogue on the Local Documents in Wenzhou Area" etc. Mr. Pan has published more then fifty papers mainly on bibliographic science and local history.

Mr. Zhang Yongsu is an associate research librarian in the Wenzhou City Library, China. 